\section{New species of three monophagous arthropods (Acari \& Hemiptera) associated with common walnut (Juglans regia) in Latvia}

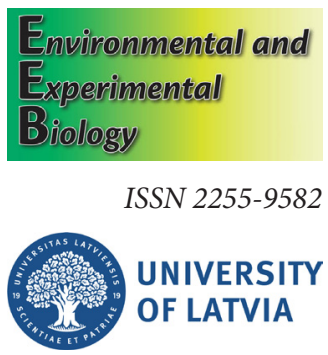

\author{
Arturs Stalažs ${ }^{1 *}$, Ineta Baka', Andrejs Svilāns ${ }^{2}$ \\ ${ }^{1}$ Institute of Horticulture, Latvia University of Agriculture, Graudu 1, Ceriņi, Krimūnu pagasts, \\ Dobeles novads LV-3701, Latvia \\ ${ }^{2}$ National Botanic Gardens of Latvia, Miera 1, Salaspils LV-2169, Latvia \\ *Corresponding author, E-mail: arturs.stalazs@llu.lv
}

\begin{abstract}
Three arthropods, including one eriophyoid mite species, Aceria erinea, and two aphid species, Chromaphis juglandicola and Panaphis juglandis, were recorded in Latvia for the first time. These species are monophages and all are associated with common walnut, Juglans regia. All three species were recorded from several localities in Kurzeme and Zemgale region in Latvia, and one species, P. juglandis was found also in Sigulda (Vidzeme region), reaching the northernmost confirmed distribution in eastern Baltic region. P. juglandis was the most abundant species and was recorded from all localities inspected, but these aphids did not occur on all trees in each locality.
\end{abstract}

Key words: Aceria erinea, alien species, aphids, Chromaphis juglandicola, mites, Panaphis juglandis.

\section{Introduction}

Common walnut, Juglans regia L., is widely cultivated worldwide. This species originates in central Asia, but due to intensive use of this crop plant as well as due to deforestation, accurate determination of its native range is impossible (Leslie, McGranahan 1998). Pollen records indicate that presence and spread of J. regia in Europe coincided with Greek settlements, suggesting that in Europe J. regia is of alien origin (Leslie, McGranahan 1998). Presently the species is widely naturalised throughout Europe (Alford 2007). As in the rest of Europe, also in Latvia J. regia was introduced, but cultivated rarely (Mauriňš, Zvirgzds 2006). During park and greenery inventories, J. regia was documented only from 40 sites (Laiviņš et al. 2009). Cultivation of J. regia in Latvia is difficult, and plants can strongly suffer during winter or even die off (Mauriņš, Zvirgzds 2006). Attempts to cultivate J. regia have been carried out since the $19^{\text {th }}$ century, but its cultivation has not always been successful due to low winter hardiness, as trees died during harsh winters, like in winter 1927-1928, and especially in 1939-1940, 1955-1956 and 1978-1979 (Saliņš, Zukovska 1985).

The first collections of J. regia and other Juglans species have been planted since 1952, but since 1957 several forest cultures with different walnut species have been established (Zukovska 1968). Notwithstanding to these growing problems in the past J. regia has been selected by horticulturists Alfrēds Ozols, Pēteris Upītis and Viktors
Vārna, who used seeds collected in mountain regions (Saliņš, Zukovska 1985; Maurin̦š, Zvirgzds 2006). Walnuts were also studied by Zelma Zukovska (Saliņš, Zukovska 1985; Āboliņa 2016). Alfrēds Ozols obtained hybrids of Juglans mandshurica and J. regia, which still grow in plant collections and parks (Saliņš, Zukovska 1985; Mauriņšs, Zvirgzds 2006). Plants grown by A. Ozols are still present in the collection of the National Botanic Gardens of Latvia. Growth of J. regia in Latvia has been limited due to unsuitable climatic conditions, but in this study we found that in some places new J. regia has been planted during the last decade, as in Ventspils in the Kurzeme region, where the climate is more appropriate for the species.

Alford (2007) lists 27 arthropod species associated with J. regia, which all are found in Europe. This list included some highly monophagous species, e. g. two gall forming eriophyoid mites: Aceria erinea, Aceria tristriata; two aphids: Chromaphis juglandicola, Panaphis juglandis; and one fly, Rhagoletis completa. Besides the two eriophyoid mites, also several other eriophyoid mites have been found in Europe, all of them being non-gall-inducing (vagrant) species associated with J. regia: Aculus arzakanensis, Aculus fascigrans, Aculus juglandis, Aculus pulaviensis, Aculus unguiculatus and Anthocoptes striatus (Flechtmann et al. 2002; Skoracka et al. 2005). According to the latest faunal reviews dedicated to particular arthropod groups (Rupais 1989; Karpa 2008; Stalažs, Turka 2019), none of the previously mentioned arthropod species occurred in Latvia in the past. 
The aim of the present study was to search for new arthropod species associated with J. regia in Latvia. As a result, three species were documented for the first time in Latvia:A. erinea, C. juglandicola and P. juglandis.

\section{Methods}

In August 2018 on one J. regia plant in Jelgava city galls were observed, which were typical damage caused by A. erinea. For that reason, walnut, Juglans species were monitored with attention to potential pests in several localities, mainly in the Kurzeme and Zemgale region, as well as in one park in Vidzeme region (Sigulda), from July to September, 2019. The visited localities are listed in Table 1.

\section{Results}

Among the monitored walnut species, leaf damage made by pests was found only on J. regia plants, not on the other Juglans species inspected. In some cases, only leaves damaged by insects were found, but it was impossible to determine the source of damage, as no adults or larvae were found.

All identified and confirmed arthropod species were found only on J. regia. These all were species found in Latvia for the first time: walnut leaf erineum mite (Aceria erinea), small walnut aphid (Chromaphis juglandicola) and large walnut aphid (Panaphis juglandis). More detailed information on the A. erinea, C. juglandicola and P.juglandis records is outlined below.

Table 1. Localities visited for studies of common walnut (Juglans regia) pests

\begin{tabular}{|c|c|c|c|c|}
\hline Locality & Locality address and coordinates & Dates visited & Habitat & $\begin{array}{c}\text { Number of } \\
\text { observed trees }\end{array}$ \\
\hline Dobele 1 & $\begin{array}{l}\text { Brīvības Street 46, Dobele, Dobele Municipality; } \\
\text { N } 56.626490 \text {, E } 23.292699\end{array}$ & $\begin{array}{l}\text { Several times since July } \\
1,2019 \text {; August 5, } 2019\end{array}$ & Home garden & 3 \\
\hline Dobele 2 & $\begin{array}{l}\text { Robežu Street 17, Dobele, Dobele Parish; N } \\
\text { 56.631343, E 23.290946 }\end{array}$ & August 5,2019 & Home garden & 1 \\
\hline Dobele 3 & $\begin{array}{l}\text { Robežu Street 39, Dobele, Dobele Municipality; N } \\
56.632143 \text {, E } 23.293455\end{array}$ & August 6, 2019 & Home garden & 1 \\
\hline Dobele 4 & $\begin{array}{l}\text { Pavasara Street, Dobele, Dobele Municipality; N } \\
56.613979 \text {, E } 23.277299\end{array}$ & August 27, 2019 & Home garden & 1 \\
\hline Dobele 5 & $\begin{array}{l}\text { Kooperācijas Street, Dobele, Dobele Municipality; } \\
\text { N 56.628672, E 23.289996 }\end{array}$ & August 29, 2019 & Home garden & 1 \\
\hline Jaundubeņi 1 & $\begin{array}{l}\text { Jaundubeņi (Pirmie Dubeņi), Ceriņu Street, N } \\
\text { 56.484602, E } 21.179229\end{array}$ & August 10, 2019 & Home garden & 1 \\
\hline Jaundubeņi 2 & $\begin{array}{l}\text { Jaunduben̦i (Pirmie Dubeņi), Ziedu Street, N } \\
56.484715 \text {, E } 21.178457\end{array}$ & September 7,2019 & Home garden & 1 \\
\hline Jaundubeņi 3 & $\begin{array}{l}\text { Jaundubeņi (Pirmie Dubeņi), Ziedu Street, N } \\
56.484528, \text { E } 21.178516\end{array}$ & $\begin{array}{l}\text { August 10, 2019; } \\
\text { September 7, } 2019\end{array}$ & Home garden & 1 \\
\hline Jelgava & Pasta Street, Jelgava, N 56.644197, E 23.728134 & August 3, 2019 & Park-like greenery & 1 \\
\hline Krimūnas & $\begin{array}{l}\text { Krimūnas, Krimūnu Parish, Dobeles } \\
\text { Municipality, N 56.569461, E } 23.378092\end{array}$ & August 12, 2019 & City park & 1 \\
\hline Liepāja 1 & Vaḷnu Street, Liepāja, N 56.496988, E 21.009371 & $\begin{array}{l}\text { July 21, 2019; August 11, } \\
\text { 2019; August 24, } 2019\end{array}$ & Home garden & 1 \\
\hline Liepāja 2 & $\begin{array}{l}\text { Kārḷa Zāles Street, Liepāja, N 56.511522, E } \\
21.016366\end{array}$ & August 24, 2019 & Park-like greenery & 2 \\
\hline Miltiņi & $\begin{array}{l}\text { “Dailes”, Miltiņi, Dobeles Municipality, N } \\
56.632574, \text { E } 23.342410\end{array}$ & August 13, 2019 & Home garden & 1 \\
\hline Rīga & $\begin{array}{l}\text { Botanic Gardens, University of Latvia, Rīga, N } \\
56.948874 \text {, E } 24.058321\end{array}$ & August 13, 2019 & Plant collection & 5 \\
\hline Sigulda & $\begin{array}{l}\text { Spiek̦u Park, Sigulda, Sigulda Municipality, N } \\
57.161770 \text {, E } 24.849553\end{array}$ & August 14, 2019 & City park & 6 \\
\hline Ventspils & $\begin{array}{l}\text { Ventspils, several home gardens at localities } \\
\text { Kurpniekciems, Gāliņciems, Zāžciems, } \\
\text { coordinates not registered }\end{array}$ & July 16 to 18,2019 & Home gardens & 5 \\
\hline Zaḷenieki & $\begin{array}{l}\text { Zal̦enieki, Zal̦enieku Parish, Jelgavas Municipality, } \\
\text { N } 56.521143 \text {, E } 23.519014\end{array}$ & August 12, 2019 & $\begin{array}{l}\text { Private plant } \\
\text { nursery park }\end{array}$ & 1 \\
\hline
\end{tabular}


Table 2. Summarised information on records of new arthropods associated with common walnut (Juglans regia)

\begin{tabular}{|c|c|c|c|c|}
\hline \multirow[t]{2}{*}{ Locality } & \multirow{2}{*}{$\begin{array}{c}\text { Number of inspected } \\
\text { trees }\end{array}$} & \multicolumn{3}{|c|}{ Number of trees infested with mites and aphids } \\
\hline & & Aceria erinea & Chromaphis juglandicola & Panaphis juglandis \\
\hline Dobele 1 & 3 & 3 & - & 2 \\
\hline Dobele 2 & 1 & - & - & 1 \\
\hline Dobele 3 & 1 & - & - & 1 \\
\hline Dobele 4 & 1 & - & - & 1 \\
\hline Dobele 5 & 1 & - & - & 1 \\
\hline Jaundubeņi 1 & 1 & 1 & 1 & - \\
\hline Jaundubeņi 2 & 1 & - & - & 1 \\
\hline Jaunduben̦i 3 & 1 & 1 & - & 1 \\
\hline Jelgava & 1 & 1 & - & 1 \\
\hline Krimūnas & 1 & 1 & - & 1 \\
\hline Liepāja 1 & 1 & 1 & 1 & 1 \\
\hline Liepāja 2 & 2 & 2 & - & 2 \\
\hline Miltiṇi & 1 & - & 1 & - \\
\hline Rīga & 5 & 4 & - & 1 \\
\hline Sigulda & 6 & - & - & 4 \\
\hline Ventspils & 5 & 5 & not searched & not searched \\
\hline Zalenieki & 1 & - & - & 1 \\
\hline
\end{tabular}

Aceria erinea (Nalepa, 1891) [Acari: Eriophyidae] - walnut leaf erineum mite

The species was found in almost all inspected localities (Table 2). For the first time, typical leaf galls (Figure 1) induced by $A$. erinea were found on one J. regia tree in August 2018 (in Jelgava), where mites were repeatedly found on the same plant in 2019. In 2019, A. erinea was confirmed in the following localities: Dobele 1 - on all trees, but the number of galls on leaves differed among trees, from a few galls on one tree to numerous on others (Fig. 2); Jaundubeni; Jelgava - number of galls on leaves (Fig. 1) in 2019 was noticeably lower than in 2018; Krimūnas; Liepāja 1; Liepāja 2; Rìga and Ventspils - on all trees inspected.

If galls were numerous, then sometimes damaged leaflets became twisted, especially at locality Dobele 1 .

\section{Chromaphis juglandicola (Kaltenbach, 1843) [Aphididae] - small walnut aphid}

This aphid species was found for the first time on one J. regia tree in the Liepāja 1 locality. Later the species was confirmed in two other localities: Jaundubeñi 1 and Miltini. In the Miltini site on two leaves collected by Edìte Kaufmane, one nymph and six mummies with parasitoids were found. Aphid mummies parasited by parasitoids were found also at locality Liepāja 1. Aphids always fed on the underside of J. regia leaves. At locality Liepaja 1, late in the growing season, this species was found together with $P$. juglandis, when colonies of $C$. juglandicola had decreased, and P. juglandis had established initial colonies (August 24, 2019) on leaves without $C$. juglandicola.
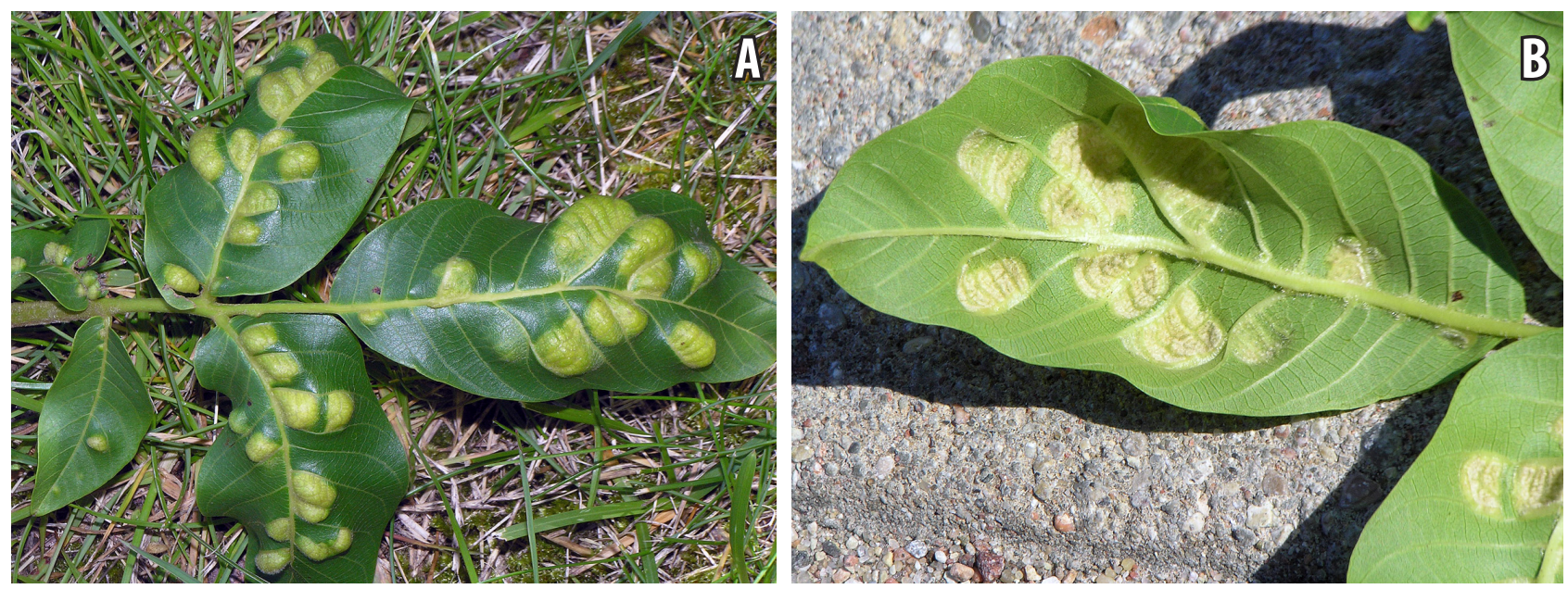

Fig. 1. Juglans regia leaf with galls induced by Aceria erinea (Ventspils, 18 July 2019). A, leaf with galls from upper side; B, leaf with galls from under side. Photo: Arturs Stalažs. 

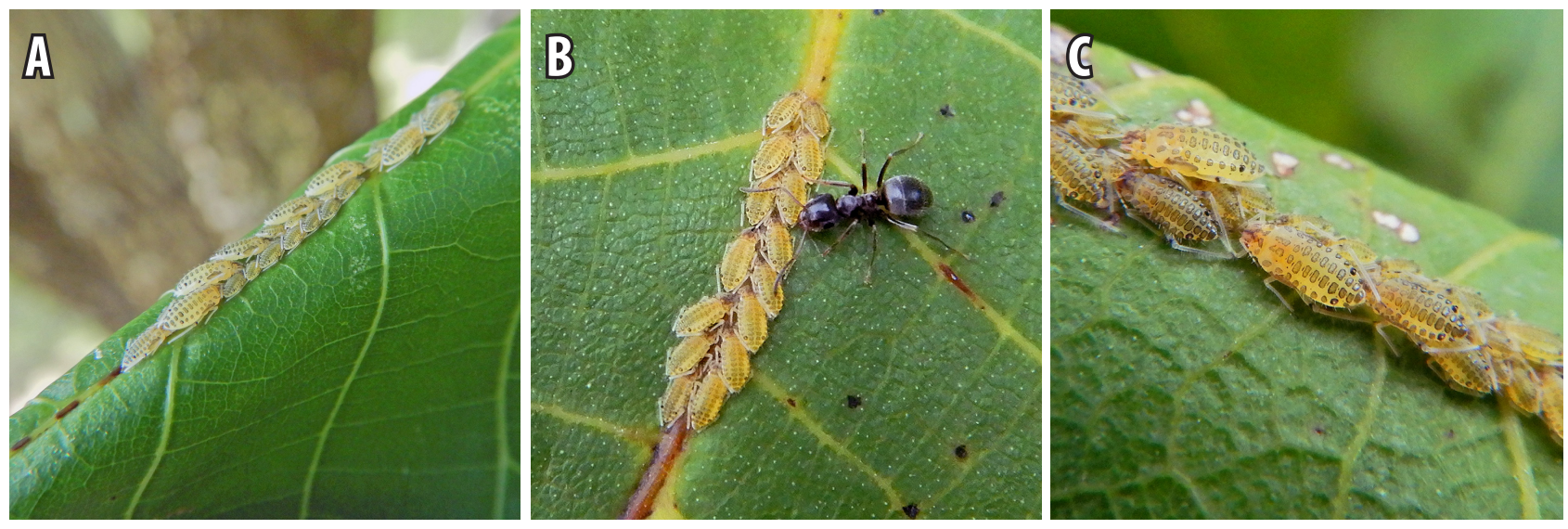

Fig. 2. Panaphis juglandis colonies on Juglans regia (Sigulda, 14 August 2019). A, an overview of colony; B, P. juglandis colony attended by ants; C, P. juglandis colony attacked by Chrysopa sp. larvae. Photo: Andrejs Svilāns.

\section{Panaphis juglandis (Goeze, 1778) [Aphididae] - large walnut aphid}

It seems that $P$. juglandis is a relatively common species. In most of the localities mainly young colonies of aphids were found, and in two localities ("Dobele 1" and "Liepāja 1 ") the species was not found earlier in the season, but was found during repeated inspections in August. In one locality ("Liepāja 1") P. juglandis was found together with C. juglandicola on the same J. regia tree. When colonies of P. juglandis occurred on this tree (August 24, 2019), the C. juglandicola colonies were scarce and later the species occurred in small numbers in comparison with high density of colonies observed earlier in the season (July 21, 2019). Colonies of $P$. juglandis frequently were attended by ants. Aphids always fed on the upper side of $J$. regia leaves, and always were in double lines along the main vein. P. juglandis was found in the following localities: Dobele 1; Dobele 2; Dobele 3; Dobele 4; Dobele 5; Jaundubeñi 2; Jaundubeñi 3; Jelgava; Krimūnas; Liepāja 1, Liepāja 2; Rīga; Sigulda and Zaḷenieki. At locality Liepāja 2, on one tree in aphid colonies, two ladybird larvae was collected and reared, which were later identified as Adalia bipunctata. Findings of P. juglandis in Sigulda is the most northern locality where the species was found in Latvia.

Numerous newly established colonies of $P$. juglandis were observed in August and September, both on trees where the species was found during previous inspections and on trees where P. juglandis was not found early in the season.

\section{Discussion}

All three arthropod species identified and confirmed in this study were new for Latvia, as never been reported in Latvia previously (Rupais 1989; Stalažs, Turka 2019). This study showed that $P$. juglandis is a relatively common species, with the widest range reaching its northernmost distribution in Sigulda. The aphid species C. juglandicola seemed to be with quite limited in distribution and was found only in the south-western part of Latvia. Probably, C. juglandicola is not able to spread widely in conditions of Latvia. P. juglandis, like the ecologically related species Appendiseta robiniae un Phyllaphis fagi, can produce more than five generations per season (Borowiak-Sobkowiak, Durak 2012), and P.juglandis males give birth to young aphids already after 14 to 17 days (Wani, Tariq Ahmad 2014). Certainly these adaptations are associated with better dispersal ability of the species. In Poland, P. juglandis population dynamics vary throughout the growing season, and depend on climatic conditions in the particular year (Karczmarz 2012). Populations with relatively high number of individuals can be found late in the season during August and September.

Usually C. juglandicola and P. juglandis do not occur together, and this can be explained by honeydew secreted by C. juglandicola (Alford 2007). A similar observation was reported by Gull et al. (2019). When individuals of $C$. juglandicola and $P$. juglandis occur on the same individual tree, they never can be found on the same leaf (Gull et al. (2019). Each aphid species feeds on different sides of leaves, with $C$. juglandicola always feeding only on the lower side (Flint 2003; Fremlin 2016). P. juglandis feeds on the upper side of leaves, usually in double rows along the midrib (Alford 2007; Fremlin 2016), as observed in the present study. As J. regia is a rarely planted species in Latvia (Mauriņš, Zvirzgds 2006; Laiviņš et al. 2009), then for these two aphid species there is no wide opportunity to select particular trees, and aphids are forced to feed on the same trees; both monophagous species are associated with J. regia only. In this study noticeable honeydew production by C. juglandicola was observed in locality "Liepāja 1", when aphids were observed on 21 July. However, on 24 August, when newly established colonies of $P$. juglandis was noticed, C. juglandicola colonies were very weak in comparison with the situation one month earlier. That explains possibility of $P$. juglandis individuals to colonise particular tree. In this part of Europe it has been observed that the main 
activity of $C$. juglandicola occurs during the first part of the season, mainly in May and June (Karczmarz 2010), but the activity can also differ during a growing seasons, with high individual density usually in July (Jaśkiewicz, Kmieć 2007). Therefore, decline of population density is common during the second part of the season. Although we observed only one case when both aphid species were on the same tree, it can be expected that in the future C. juglandicola and $P$. juglandis probably will often occur on the same trees due to deficiency of host plant species in Latvia. This assumption is based on the fact that the only known host plant, J. regia (Magnussen, Hansen 2014), in Latvia occurs in small numbers. Although $P$. juglandis accidentally has been documented also on other Juglans species (as reviewed by Juronis, Rakauskas 2004), there is no doubt that these reports demonstrate only rather exceptional cases but not normal behaviour of this species. This has been confirmed also in the present study, as no C. juglandicola or P. juglandis where found on other Juglans species inspected. Recently the same was found in Norway (Magnussen, Hansen 2014). However, in Korea C. juglandicola has been found also on other Juglans species, e. g. J. mandshurica and J. sinensis (Lee et al. 2018).

Presently, C. juglandicola and P. juglandis have Eurasian distribution, and both species were introduced in North America (Sluss 1967; Alford 2007; Andersen, Mills 2017; Wieczorek et al. 2019). C. juglandicola has also been introduced in Africa (Algeria, Canary Islands and Tunisia) and South America (Argentina and Chile) (Salas et al. 2016; CABI 2017). It seems that $C$. juglandicola is a highly economically important species, especially on young trees and nursery stock (Alford 2007; Gull et al. 2019). In the past, a specific parasitic wasp was introduced in California for control of C. juglandicola (van Den Bosch et al. 1979). Since introduction of this parasitic wasp species, C. juglandicola is no longer a major pest of J. regia in this region (Flint 2003). Recent findings of both aphid species in new territories in Europe (Magnussen, Hansen 2014) and in other parts of the World (Salas et al. 2016; Lee et al. 2018) indicate that these aphids will continue their spread worldwide.

Movement of $C$. juglandicola and $P$. juglandis to nortthernly locations in Europe and appearance of both species in Latvia was predictable. Recently expansion of the species was recorded in Scandinavia, when both aphids were found in Norway (Magnussen, Hansen 2014). One of these aphid species, $P$. juglandis, was previously reported from Lithuania (Juronis, Rakauskas 2004). The northernmost finding of $P$. juglandis in this part of Europe now has moved to Latvia, since the aphid was found also in Sigulda. In contrast to P. juglandis, the northernmost occurrence of C. juglandicola in this part of Europe was previously considered to be Poland (Krzyżanowski 2017). As previously reported (Alford 2007; Fremlin 2016), we observed that $P$. juglandis populations were frequently attended by ants.
Similarly to aphids, also A. erinea originates from Asia and has a large worldwide distribution in areas where $J$. regia is cultivated (Chireceanu et al. 2015). Nowadays this eriophyoid mite species is present in Australia, Eurasia, North America and New Zealand (Boczek 1964; Skoracka et al. 2005; Alford 2007; Chireceanu et al. 2015). The two Aceria species, A. erinea and A. tristirata sometimes have been synonymised (Boczek 1964). These two species induce specific leaf-galls on J. regia, and the shape of induced galls is well distinguishable for each mite species (Skoracka et al. 2005; Alford 2007; Chireceanu et al. 2015). A. erinea produces large felty masses of erineum on the underside of leaves (Skoracka et al.2005) and usually there are several galls per leaf (Alford 2007), but A. tristirata induces a large number of small galls up to $2 \mathrm{~mm}$ diameter, which usually are placed among mid and other veins, where mites live in intracellural spaces of mesophyll (Skoracka et al. 2005; Alford 2007; Chireceanu et al. 2015). A. erinea do not cause economically important damage (van Steenwyk, Barnett 1998; Flint 2003; Alford 2007). The nearest previous finding of A. erinea was in Poland (Skoracka et al. 2005), but in August 2019 heavy infested trees were also observed in Klaipēda, Lithuania (A. Svilāns, unpublished data).

Results of this study demonstrate that alien species in Europe have continued to spread in the northern direction, especially narrowly specialised ones, like these three monophagous arthropod species. There are two possible reasons for this: warming as a result of climate change or human activity due to transfer of planting material. It is highly predictable that several other narrowly specialised monophagous or oligophagous species will reach the territory of Latvia in the nearest future.

\section{Acknowledgements}

Thanks to Edìte Kaufmane (Institute of Horticulture) for J. regia leaf samples with aphids collected in Miltini village, and to Vija Bārdiņa (National Library of Latvia) for providing the older literature.

\section{References}

Āboliņa A. 2016. My first work years (memories). Latvijas Veǵetācija 25: 121-126. /in Latvian/

Alford D.V. 2007. Pests of Fruit Crops. Academic Press, Boston. 461 p.

Andersen J.C., Mills N.J. 2017. Comparative genetics of invasive populations of walnut aphid, Chromaphis juglandicola, and its introduced parasitoid, Trioxys pallidus, in California. Ecol. Evol. 8: 801-811.

Boczek J. 1964. Studies on eriophyid mites of Poland. III. Ann. Zool. 22: 221-236.

Borowiak-Sobkowiak B., Durak R. 2012. Biology and ecology of Appendiseta robiniae (Hemiptera: Aphidoidea) — an alien species in Europe. Centr. Eur. J. Biol. 7: 487-494.

CABI 2017. Datasheet: Chromaphis juglandicola (walnut aphid, European), last modified 11 October 2017. Available at https:// 
www.cabi.org/isc/datasheet/13137 (accessed 25 October 2019).

Chireceanu C., Chiriloaie A., Teodoru A., Sivu C. 2015. Contribution to knowledge of the gall insects and mites associated with plants in southern Romania. Sci. Pap. Ser. B Horticulture 59: 27-36.

Flechtmann C.H.W., Auger P., Veraeghe A., Cambronne N., Kreipter S. 2001. The eriophyoid mites (Acarina) from walnut trees in Grenoble (Isere, France). Acarology 42: 379-388.

Flint M.L. (techn. ed.) 2003. Integrated pest management for walnuts. $3^{\text {rd }}$ Ed. University of California, Oakland, $136 \mathrm{p}$.

Fremlin M. 2016. The large walnut aphid (Panaphis juglandis Goeze) - a few observations. Nature in North-East Essex 2016: 68-76.

Gull S., Ahmad T., Rasool A. 2019. Studies on diversity indices and insect pest damage of walnuts in Kashmir, India. Acta Agric. Slov. 113: 121-135.

Jaśkiewicz B., Kmieć K. 2007. The occurrence of Panaphis juglandis (Goetze) and Chromaphis juglandicola (Kalt.) on walnut under the urban conditions of Lublin. Acta Sci. Pol. Hort. Cultus 6: 15-26.

Juronis V., Rakauskas R. 2004. Recent additions to the aphid (Hemiptera, Sternorrhyncha: Aphididae) fauna of Lithuania. Acta Zool. Lituanica 14: 67-70.

Karczmarz K. 2010. Numerical strength dynamics of Chromaphis juglandicola (Kalt. 1843) on common walnut (Juglans regia L.) in Lublin town plantings. Acta Sci. Pol. Hort. Cultus 9: 121132.

Karczmarz K. 2012. Dynamics of population and bionomics of Panaphisjuglandis (Goeze, 1778) (Homoptera, Phyllaphididae) on common walnut (Juglans regia L.) in Lublin's parks and gardens. Acta Sci. Pol. Hort. Cultus 11: 53-70.

Karpa A. 2008. Catalogue of Latvian flies (Diptera: Brachycera). Latvijas Entomologs 46: 4-43.

Krzyżanowski R. 2017. Population dynamics and spatial distribution of Chromaphis juglandicola (Kaltenbach, 1843) (Hemiptera: Phyllaphididae) on common walnut (Juglans regia L.) at home gardens and street tree plantings in Siedlce. Prog. Plant Prot. 57: 211-218. /in Polish/

Laiviņš M., Krampis I., Šmite D., Bice M., Knape D., Šulcs V. 2009. Latvijas kokaugu atlants: Atlas of Latvian woody plants. Latvijas Universitātes Biolog̣ijas institūts \& Apgāds Mantojums, Rīga, $606 \mathrm{p}$.

Lee Y., Kim S., Lee S. 2018. A first record of three aphid pests (Aphididae: Calaphidinae) on walnut in Korea. J. Asia-Pacific
Biodivers. 11: 531-537.

Leslie C.A., McGranahan G.H. 1998. The origin of the walnut. In: Ramos D.E. (Ed) Walnut Production Manual. University of California, Oakland, pp. 3-7.

Magnussen T., Hansen L.O. 2014. Panaphis juglandis (Goeze, 1778) and Chromaphis juglandicola (Kaltenbach, 1843) (Hemiptera, Aphididae) in Norway - two aphid species associated with common walnut (Juglans regia L.). Norw. J. Entomol. 61: 186189.

Mauriņš A., Zvirgzds A. 2006. Dendrology. Akadēmiskais apgāds, Rỉga, 448 p. /in Latvian/

Rupais A. 1989. The Aphids (Aphidodea) of Latvia. Zinātne, Rīga, 331 p. /in Russian/

Salas C., Quiroz C., Luengo F. 2016. First record of Chromaphis juglandicola (Kaltenbach) (Hemiptera: Aphididae) overwintering eggs in commercial walnut orchards in the Coquimbo region with biological notes. Rev. Chilena Entomol. 41: 79-82.

Salinšs S., Zukovska Z.1985. Walnuts in Latvia. Mežsaimniecība un Mežrūpniecība 3: 5-8. /in Latvian/

Skoracka A., Lewandowski M., Boczek J. 2005. Eriophyoid Mites (Acari: Eriophyoidea) of Poland. Natura optima dux Foundation, Warszawa, $199 \mathrm{p}$.

Sluss R. R. 1967. Population dynamics of the walnut aphid, Chromaphis juglandicola (Kalt.) in northern California. Ecology 48: 41-58.

Stalažs A., Turka I. 2019. Eriophyoid mites (Acari: Prostigmata: Eriophyoidea) of Latvia: an annotated checklist. Zootaxa 4629: 211-236.

van Den Bosch R., Hom R., Matteson P., Frazwer B.D., Messenger P.S., Davis C.S. 1979. Biological control of the walnut aphid in California: impact of the parasite, Trioxys pallidus. Hilgardia 47: 1-13.

van Steenwyk R.A, Barnett W.W. 1998. Insect and mite pests. In: Ramos D.E. (Ed) Walnut Production Manual. University of California, Oakland, pp. 247-253.

Wani S.A., Tariq Ahmad S. 2014. Laboratory study of parthenogenesis and fecundity of dusky-veined aphid, Panaphis juglandis Geoze (Hemiptera: Aphididae). Researcher 6: $1-4$.

Wieczorek K., Fulcher T.K., Chłond D. 2019. The composition of the aphid fauna (Insecta, Hemiptera) of the Royal Botanic Gardens, Kew. Sci. Rep. 9: 10000.

Zukovska Z. 1968. Walnuts in Latvian parks and forests. Mežsaimniecība un Mežrūpniecība (4): 42-44. /in Latvian/ 